\title{
ARTHUR REGINALD PRINCE, 1900-1969
}

\section{by C. D. Bird, Department of Biology, University of Calgary}

It was with deep regret and a real sense of loss that Canadian biologists, and botanists in particular, learned of the passing of A. R. Prince in Calgary on April 16, 1969.

Mr. Prince was born, and grew up, in Truro, Nova Scotia. He obtained a B.A. degree from Acadia University in 1922, and an M.A. from Harvard in 1924. He taught biology at the Nova Scotia Agricultural College from 1926 until 1933. During this period he made extensive collections of the local plants and, to a somewhat lesser extent, of the insects. Mr. Prince held various high school teaching positions in the Maritimes and in Quebec from 1933 until 1949. He then moved to Calgary where he taught at Mount Royal College for two years before joining the University of Calgary, at that time a branch of the University of Alberta.

Mr. Prince was the first biologist hired by the University of Calgary. Starting at the rank of Assistant Professor, he was promoted to Associate Professor in 1955, and remained with the University until his retirement in 1966. During this period he taught courses in Introductory Biology, Introductory Zoology, Introductory Botany, Plant Anatomy and Lower Vascular Plants. He had contact with a large number of students in these courses many of whom have since taken positions in various biological fields. He will be remembered by his students as a sincere, meticulous, and friendly perfessor whose first interest was teaching and whose primary concern was that of the betterment of his students.

The University of Calgary was very small when Mr. Prince came on staff in 1951 and was located beside Highway 1 in buildings now occupied by the Southern Alberta Institute of Technology. As Acting Head of the Department of Botany from 1956 to 1964 he played an active role in the planning of the Science and Engineering Building on the new (and present) campus

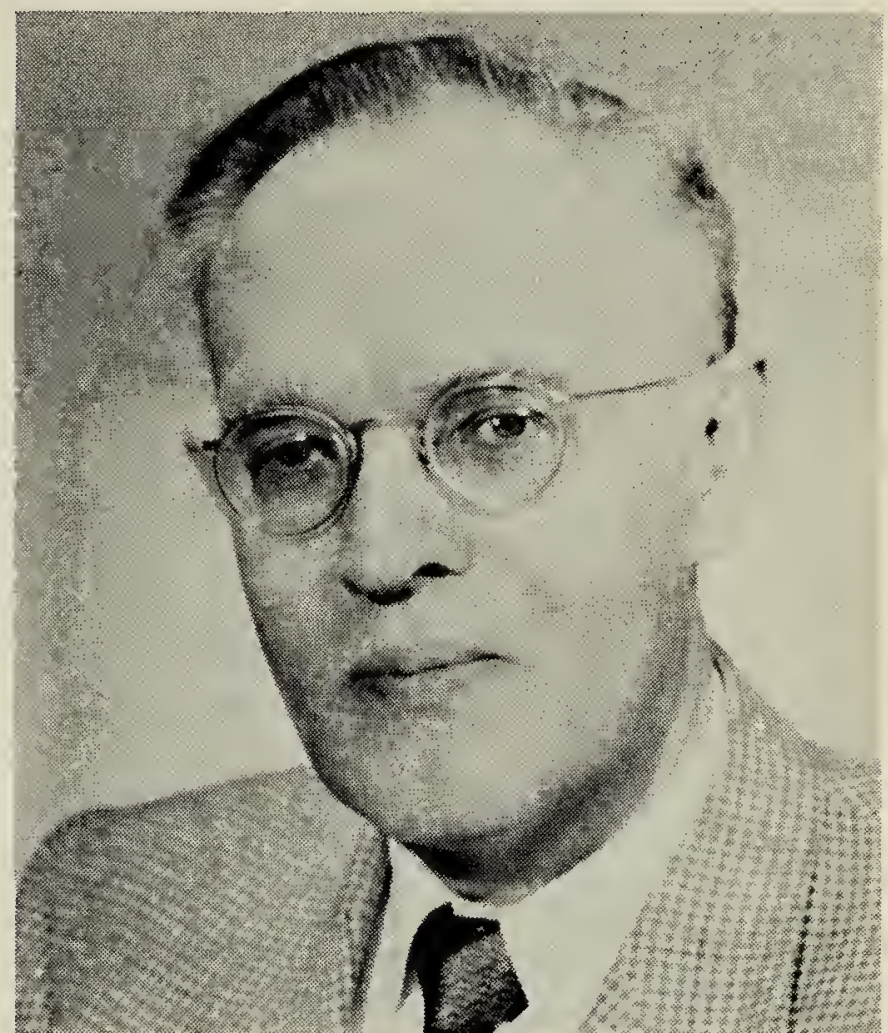

occupied in 1961 and was involved in many administrative duties.

In his early years in Calgary, the demands of teaching and administrative duties left him little time for research. Later on his duties eased a little and he developed a keen interest in the local cryptogamic flora, and especially in the lichens and bryophytes. Though a physical handicap prevented him from carrying out extensive field work he was helped by his sons, one of whom, Richard, is now in a Ph.D. program in botany at the University of Aberdeen.

The Department of Biology is particularly grateful to Mr. Prince for the donation of a large number of biology books, and his insect collection. His biggest, and most valuable donation, however, was that of his plant collection which is now in the Department's Herbarium. It contains 8634 specimens of which 2029 are lichens, 325 are liverworts, 3894 are peat mosses and mosses, and 2388 are vascular plants. Approximately three-quarters of these specimens are from Nova Scotia and elsewhere in the eastern part of the continent. 
In addition to his teaching, administrative and research interests, Mr. Prince was a keen gardener, numismatist, and photographer. He was also a faithful member of the I.O.O.F. St. George Lodge No. 39 and an active member of iSt. John the Evangelist Anglican Church.

I feel a deep personal loss at his death as he was a close friend of mine from the time I joined the staff in 1962 . With our joint interest in lichens and bryophytes we had much in common.

$\mathrm{Mr}$. Prince is survived by his wife Honor; four sons, John, Henry, Richard, and Theodore; and a sister, Mrs. Elaine Wehmeyer.

Mrs. Prince, in her husband's memory has established The Reg Prince Memorial Prize in Botany to be awarded annually to a student proceeding into the fourth year of a B.Sc. Botany programme at the University of Calgary.

\section{NOTES ON ERUCA SATIVA, THE PIONEER'S POT-HERB}

\section{by B. M. Hallworth, The Herbarium, Biology Department, University of Calgary}

Eruca sativa Mill. is a member of the mustard family, Cruciferae. It is a large, $\quad 20-100 \mathrm{~cm}$ high, spreading, rough-hairy annual or biennial, with interesting flowers. These are large, compared with those of other members of the Cruciferae; the petals are 1.5 - 2 $\mathrm{cm}$ long and are pale yellow. They have distinctive violet, sometimes brown, veins. The silique has a welldeveloped beak, and is similar to that found in the genus Brassica. The two genera are closely allied, but Eruca fruits have two rows of seeds in each valve whereas Brassica fruits have only one. Eruca can be distinguished from other yellow-flowered mustards in two ways; it has a fruit with a prominent beak, and the petals have the characteristic vein-markings. One of our related mustards, Erucastrum gallicum, gets is generic name from its resemblance to Eruca.

Eruca sativa is a native plant of the Mediterranean area, and for many years it has been cultivated as a salad plant and vegetable, and for the medicinal oil obtained from its seeds. The species name, sativa, from the Latin word for "sown", reminds us that it is a cultivated plant, and its common name, Rocket Salad, also suggests this. Eruca vesicaria (L.) Cav. is sometimes given as a synonym.

The pioneer settlers in Ontario brought seeds of Eruca from Europe and grew them for use as pot-herbs and in salads. Some plants escaped from cultivation and became weeds. Eruca seeds were also brought from Europe mixed with alfalfa seed (Clarke \& Fletcher, 1909). Farmers from various parts of Ontario sent samples to the Experimental Farm, Ottawa. These came from Preston (1907), Galt (1908), Manitick (1909); East Linton, Wingham, and Laurier (1910) ; and from Melbourne, Markdale, and Palmerston (1911). John Macoun, the "Father of Canadian Botany", collected a plant near Ottawa in 1911. The plants had also spread to the West in alfalfa seed, but there is no reference to them being planted as pot-herbs in that region. There are reports at the Herbarium of the Plant Research Institute, Ottawa, from near Regina (1907), Bradwell (1910), and from Carnduff (1912). There are only two records of it from Alberta, from Olds (1910), and from Lacombe (date uncertain, probably before 1912). There is no record of Eruca sativa in the West after 1912. B. Boivin points out (Boivin, 1968-1969) that in many cases these dates and localities are not substantiated by actual specimens. Eruca sativa is not mentioned in the Flora of Alberta by E. H. Moss, and H. J. Scoggan has excluded it from the Flora of Manitoba because of lack of evidence.

In August, 1969, I found some plants of Eruca sativa growing on waste 